\title{
Anton Tomaž Linhart Between the German and the Slovenian Language
}

\begin{abstract}
Strsoglavec Đurđa, Anton Tomaž Linhart Between the German and the Slovenian Language. „Poznańskie Studia Slawistyczne” 5. Poznań 2013. Adam Mickiewicz University Press, pp. 321-332. ISBN 978-83-232-2636-9. ISSN 2084-3011.
\end{abstract}

\begin{abstract}
Anton Tomaž Linhart (1756-1795), is a critical intellectual and scholar of the age of Slovenian Enlightenment, who introduced causal interpretation of history into Slovenian historiography and started its scientifical philosophy by his historical work Versuch einer Geschichte von Krain und den übrigen Ländern der südlichen Slaven Österreichs (1778, 1791). He was an open-minded man, at first deist under the influence of English philosophers, and afterward agnostic under the influence of French materialists and atheists, a man torn between his work as a scholar and a reformer and between the German and the Slovenian language. Linhart's first works were written in German. Miss Jenny Love (1780) is an attempt of a tragedy, written according to the rules of the Enlightenment period tragedy, exhibiting the contrast between the corrupted nobility and the middle class. The collection of poems Blumen aus Krain für das Jahr 1781 is Linhart's attempt of contemporary classicist poetry in the rococo fashion and after the manner of the Anacreontic and even Pre-Romantic poetry. Linhart wrote his first Slovenian-language drama Županova Micka (1789), while his second Slovenian drama called Ta veseli dan ali Matiček se ženi (1790) is the most important literary work of the Slovenian Enlightenment and the most wide-ranging echo of the French revolution in the Slovenian literary production of the $18^{\text {th }}$ century. Linhart's dramas Županova Micka and Matiček are a manifesto of Slovenehood and democracy expressed in dramatic form, and a declaration of support to the Slovenian people and their struggle against feudalism.
\end{abstract}

Keywords: Slovenian Enlightenment; Anton Tomaž Linhart; social and functional language stratification; Slovenian historiography 


\section{The Slovenian Enlightenment and its Historical Context}

The unfettering of the human mind during the Renaissance intensified in the $18^{\text {th }}$ century and acquired a new and deeper meaning, as the unlimited expansion of emotions gave way to reason as the prime mover of all the manifestations of human life. From arts to politics, the need to expand exact knowledge was given prominence. In Central and Eastern Europe the Enlightenment that incorporated national tendencies prevailed (in Western Europe so called national question had already lost its topicality), as well as its didactic and educational ideas influencing Slovenian literary production.The Enlightenment spelt a new ascent for Slovenian literature and culture in general, after a profound stagnation in the $17^{\text {th }}$ and the first half of the $18^{\text {th }}$ century. It is from that time on that we can speak about Slovenian secular literature. To speak about the Slovenian Enlightenment is to speak about the time of the Slovenian national Reawakening.

The Slovenian Enlightenment put the ethnic and national question to the foreground and emphasized man's natural origin, his natural rights and distinctive traits, and his emotional and experiential self. Part and parcel of these are the mother tongue and the individual's belonging to an ethnic group, to a national environment, a nation and a culture. It thus became clear that it is man's natural right, indeed an obligation, to cultivate and foster his language, national consciousness and his culture.

At the time of their encounter with the Enlightenment, the Slovenian ethnic lands were divided into three states ruled by two sovereigns. The largest part belonged to the Holy Roman Empire of the German nation, ruled successively by Maria Theresa, Joseph II, Leopold II and Francis II. The Prekmurje region was under Hungary, and a smaller part of the Slovenian population lived in the territory of the Venetian Republic. Austrian absolutism opposed the expansion of native languages and imposed the use of German. The Slovenian language became the language of classroom lessons only in 1810, at the time of Napoleon's Illyrian Provinces. Before that, the languages of classroom lessons in primary and grammar schools were Latin and German, and books by Slovenian authors were printed in Latin and German. Since only intellectuals were able to read such books, the ideas of the Enlightenment had to be adapted to the receptive ability of the people. 


\section{Development of the Slovenian Literary Language in the $18^{\text {th }}$ Century}

The second half of the $18^{\text {th }}$ century was marked by the ideology which historians referred to as Josephinism and which later made a qualitative leap to liberalism and deism. One of the essential tasks that Josephinism had imposed on priests was to make their sermons more accessible to their congregations, meaning that they had to be delivered in the native languages, including Slovenian. Priests were also expected to have practical economic knowledge, thus numerous practical works were translated into Slovenian. Linhart, for example, translated Wolstein's popular manual on domestic animal diseases (Bukve od kug inu bolezni goveje živine, tih ovac inu svinj, The Book on the Cattle Plague and Cattle, Sheep and Sow Illnesses, 1792) from German into Slovenian language.

Although typical works of the time - historical and scientific writings and correspondence - were still written in other languages, the age of Enlightenment saw, for the first time after the folk literature of the Middle Ages, the development of the Slovenian literary language in the proper sense of the word. The age of Enlightenment is also considered to be the beginning of the Slovenian drama (written after European dramatic models and adaptations), for which the credit goes to ,the first Slovenian European" (Svetina 2005: 12) Anton Tomaž Linhart, the only scholar of the Slovenian national Reawakening ${ }^{1}$. He possessed a critical mind, and through his historical work introduced the causal interpretation of history and its scientific philosophy, he had a liberal frame of mind and under the influence of English thinkers professed deism and later embraced agnosticism under the influence of French materialists and atheists; he was a man torn between his work as a scholar and a reformer and between the German and the Slovenian language ${ }^{2}$.

${ }^{1}$ „In the initial phases of the Slovenian Reawakening we had two great scholars, Linhart and Kopitar, and two great texts - Linhart's An Attempt of History... and Kopitar's Grammar. Linhart was the first of the two, the only scholar of the Slovenian Reawakening in the $18^{\text {th }}$ century, and that is where his significance lies" (Zwitter 1957: 13).

2 Janko Kos (2007: 448-449) thinks that based on Linhart's linguistic knowledge we can conclude about his literary horizon in his early years what can help us to understand also the structure of his works and their meaning; he also thinks that the question about the Linhart's works language is also the question about his linguistic, family and social orientation. 


\section{Linhart's German Literary Beginnings}

Anton Tomaž Linhart was born in 1758 in Radovljica to Venčeslav Linhart, an immigrant from Moravian Ivančica, and Terezija Linhart, nee Kunstl, from an old Radovljica family. After finishing the Jesuitical grammar school in Ljubljana in 1776 he went to the Cistercian monastery at Stična. Disappointed by the monastery he left it in 1778 and went to study in Vienna. On returning from Vienna (if not at the very moment he had left Stična) he adopted a critical attitude towards monks and in 1781, in the first session of the renewed Academia Operosorum (the Academy of the Working Ones), made public his adherence to the ideas of the Enlightenment (cf. Linhart 1950c: 448-450). The worldview he professed in his collection of poems in the German language Blumen aus Krain (1781) (Flowers from Carniola) is $18^{\text {th }}$ century deism, the belief that after receiving the initial impulse from God the world develops according to the laws of nature and man, which makes any subsequent divine interventions and religious revelations unnecessary and untrue.

Linhart's first works were written in German. Miss Jenny Love (1780) is an attempt of a tragedy, written according to the rules of Enlightenment period tragedy, exhibiting the contrast between the corrupted nobility and the middle class. The tragedy in which the heroine must suffer maltreatment by a ruthless and almost pathologically violent nobleman is set in Scotland. Linhart's criticism of the nobility is not of the severest kind, for actually the tragedy is not about the conflict between nobility and the middle class but between the upper and lower nobility. The tragedy evinces the influence of Shakespeare, who in the Pre-Romantic era was considered to portray atrocious, gloomy and pathologically violent characters and events.

The collection of poems Blumen aus Krain für das Jahr 1781 (Flowers from Carniola for the year 1781) is Linhart's attempt of contemporary classicist poetry in the rococo fashion and after the manner of the Anacreontic and even Pre-Romantic poetry in the German language. He wrote following the model of Horace, Lessing, Metastasio, Ossian and others, but with no significant success (cf. Zupančič 1972: 85; Kos 2007: 450). The collection Blumen aus Krain is important because it contains the hexameter translation of the Slovenian oral poem Pegam and Lamberger into German, which demonstrates both the classicist and Pre-Romantic imagina- 
tion, and because of Linhart's intention expressed in the preface ,to convince the neighbours in the north that there, in our non-German mountainous country, sprout here and there, between thorns and thistle, flowers whose fragrance, though not truly Ambrosian, is nevertheless acceptable" (Linhart 1950b: 366).

Slovenian Enlightenment authors who wrote in German were in contact with the European literary works of the time and their creative work enriched the domestic cultural scene with new literary attainments. Linhart with his collection Blumen aus Krain opened up, in effect, a whole repertoire of Pre-Romantic pursuits and acquainted the Slovenian, i.e. Carniolan, intellectuals with the wave of Ossianism which found adequate expression in the Slovenian Enlightenment literature in scenic, love and patriotic poetry and in bourgeois drama. Yet what was easily most important was his endeavour to prove that it is possible to write a literary work in the Slovenian language.

\section{Linhart's Works in the Slovenian Language}

The year 1781 is the turning point in Linhart's creative work. That year he abandoned plans to become a German-Carniolan, i.e. GermanSlovenian poet, joined baron Žiga Zois' circle of Slovenian Enlightenment figures and started to write intensively in Slovenian ${ }^{3}$. Zois introduced new ideas into Slovenian culture and literature. He organised and directed the work of Slovenian Enlightenment activists. Above all, he was a tutor, a critic and a patron. He urged the writing of works that are fundamental to any national literature, i.e. a dictionary, a grammar book, historical books, didactical works and genuinely secular works in the Slovenian language.

Writers who wanted to write in Slovenian in the second half of the $18^{\text {th }}$ century faced the problem of the simultaneous existence of four different Slovenian literary languages - Carniolan, Carinthian, Styrian and the language of Prekmurje. Members of Zois' circle, Linhart and Valentin Vodnik in particular, take great credit for preserving, by relying on the

\footnotetext{
3 About ,turnabout" that happened in Linhart when he abandoned writing in German, cf. Poniž 2012.
} 
Slovenian Protestant tradition, the continuity of the Slovenian language and enabling it to become the language of all Slovenians.

Linhart wrote his first Slovenian-language, i.e. Carniolan-language, drama in 1789 for the Theatrical Club, a group of amateurs from Ljubljana who staged occasional performances in German. He translated and adapted the Austrian playwright Joseph Richter's drama Die Feldmühle which he entitled Županova Micka (The Mayor's daughter Micka). The plot is quite simple: a noble bon vivant wants to trifle with the village mayor's candid daughter, although he is engaged to a young widow. The widow herself opens the eyes of the girl and in the end the nobleman is unmasked and disgraced and the mayor's daughter marries an honest young villager. Linhart sets the play, actually transposes it, in an authentic rural environment, thus at the same time solving the problem of the language. Since the refined speech of the middle class simply could not be worked into the $18^{\text {th }}$ century Slovenian, the choice of the rural environment made it only natural to use the living speech of the common people. Linhart's ingenious building on Richter's drama, which also had an ideological significance in the Slovenian circumstances of the time, is manifested in the choice of names of the characters: all the villagers have local names (Jaka, Micka, Anže) while the scheming noblemen have foreign names (Tulpenheim, Monkof, cf. Paternu 1989: 745). In this way his critical perception touches upon both social and national concerns.

The first Slovenian-language theatrical performance was an enormous success. The next day (29 December 1789) the Laibacher Zeitung published a glowing German-language review of the performance by an anonymous critic who particularly praised the actors for proving that Slovenian on stage is as lively, flexible and melodious as any Slavic language. It would appear, however, that the review was written by Žiga Zois, or even by Linhart himself. His second Slovenian-language drama, $\mathrm{Ta}$ veseli dan ali Matiček se ženi (The Merry Day or The Marriage of Matiček; 1790), is the most important literary work of the Slovenian Enlightenment. It is the farthest-reaching echo of the French Revolution in the $18^{\text {th }}$ century Slovenian literary production - assuming, that is to say, that we view a free individual and a free nation as one of its essential intentions and characteristics. The recurring theme of Linhart's Matiček is Rousseau's and Montesquieu's thought that nature endows all her children with 
equal dignity and that these children - as individuals and as peoples - have equal rights to self-fulfilment ${ }^{4}$. The comedy is an adaptation of Beaumarchais' The Marriage of Figaro, first put on stage in 1784, which Linhart again sets in the Slovenian environment. Thus in Linhart's rendering, Beaumarchais' open criticism of French aristocracy turns into a satire upon the Carniolan landed gentry who live next to the common people, upon the political system and the inconvenience of the bureaucratic mixing of Latin, German and Slovenian, i.e. Carniolan. Figaro, the sharp-witted, difficult and complex representative of the French Enlightenment age, in Linhart's play becomes the provincial squire's simple gardener Matiček. But the idea is the same: conflict between morally corrupted nobility and the oppressed lower class ends with the victory of the ordinary people's common sense. The most compelling part of Linhart's comedy is the scene in court in which he satirically portrays Slovenian conditions, the conservative nobility's opposition to court concessions for peasants and the neglecting of Slovenian in official communication ${ }^{5}$.

The biggest problems Linhart had to cope with in his play were due to the lack of social and functional stratification of the Slovenian language at the time, which he fairly successfully resolved by individualizing the speech (e.g. by using „thou” and ,they” instead of „you” and „he” or „she”), and the lack of a refined middle-class speech, which he resolved by assigning lower social position to his characters. There, in the Beaumarchais' play the count and his noble friends who speak the refined language of educated French society appear, whereas Linhart's characters are the Carniolan provincial gentry and their subjects who speak the language of the peasant/landed-gentry milieu.

4 „Al je kej bolši koker jest? Vzemi mu dnarje, žlahto, ime, potegni mu doli to prazno odejo inu postavi ga kje, koker je človek sam na sebi, tok ne bo vreden, da bi on meni služil!" (Is he better than me in any way? Take away from him his money, nobility, name, pull off this empty blanket and put him somewhere as a man himself, and he will not be worthy to serve me!) (Linhart 1950a: 111-112).

5 ,Linhart's criticism was mainly enlightening legitimate because it arose from the Josephinian reformism. But it also exceeded those limits, namely with the criticism of the state unitarian linguistic policy which germanised administration and education and with the protection of the language rights of Slovenians on their own soil. Matiček resolutely resists against imposed foreign language and irrespective of everything takes his natural right to speak in the language of his own" (Paternu 1989: 746). 
Although everything was ready for the performance, even the Mozartstyle music for vocal parts, Linhart did not live to see the premiere of his second Slovenian-language play. After the death of Joseph II (1790) the regime became much less tolerant of nationalist tendencies and free thinking in general, and the situation worsened further during Metternich's absolutism in the first half of the $19^{\text {th }}$ century. Thus Matiček first appeared on stage only in the year of the spring of nations - 1848. In responding to the general mood of the time, the editor, Miha Kastelic, made the comedy topical again by adding the demand for the opening of a university in Ljubljana.

Through his Slovenian-language comedies Linhart not only lent a universal value to Slovenian drama but also proved that he was able to show concern for and be one with his people. The enlightening of the people was his supreme concern (cf. Paternu 1989: 737), a memorable testimony of which is his passionate urging in the first session of the renewed Academy of the Working Ones: „Let us hasten with burning desire towards the goal; let us not tire in our search for the truth in the darkest corners, and when we find it let us pounce on it with the greediness of a miser so that we can spend it with the generosity of a prodigal on the well being of the homeland!" (Linhart 1950c: 450), and the invitation to his friend Martin Kuralt in Poland: „My friend! If only you were here so that we could together devote ourselves to educating our people. What a wonderful idea!" (Linhart 1950d: 436).

Inherent in Slovenian Enlightenment thought was the idea of the opening of a scientific library. In an extensive letter (cf. Linhart 1950d: 545550) written in 1784 Linhart urged the gathering at one place of the book stocks of private libraries and libraries of closed-down monasteries. The idea was realized in 1791 by founding of a grammar-school library in Ljubljana, which marked the beginning of the present-day National and University Library of Slovenia.

\section{From Poet and Playwright to Historian}

Linhart's dramas Županova Micka and Matiček are a manifesto of Slovenehood and democracy expressed in dramatic form, and a declaration of support to the Slovenian people and their struggle against feudalism. 
These ideas are made still more explicit in the most important of his works, his German-language historical work Versuch einer Geschichte von Krain und den übrigen Ländern der südlichen Slaven Oesterreichs (An Attempt of the History of Carniola and Other South Slavs of Austria) published in 1778 (first part) and 1791 (second part). The work was not important for the development of Slovenian historiography alone but also for Slovenian literary thought, especially in the second half of the $19^{\text {th }}$ century. The significance of the work can only be understood if we examine it within the context of the historical development of the problems it deals with and combine our analysis with historical facts. In this work Linhart advances the thesis that the people living in the territory about which he writes are one nation and contrasts national history with the history of individual provinces. In the Laibacher Zeitung in 1786 Linhart announced the publication of the first part of the book with these words:

The people that live in the southern part of the Austrian department between the Drava and the Adriatic and belong to the big, distinctive, Slavic human tree, and by their language and origin represent one and the same human branch and are only accidentally - though, from the standpoint of history, not quite accurately classified into Carniolans and Vinds, deserve indeed to have their own history written. So far we have had it piecemeal in the scattered chronicles of provinces in which these people live, but never in the totality of their interrelated destinies and experiences (Zwitter 1957: 9).

In Linhart's history there are no strange or supernatural events. Unlike his predecessors, he makes no attempt to relate the beginnings of his history to biblical tradition. A critical stand and documentary sources are his first concerns. In order to reconstruct the historical circumstances of the old Slavs he made extensive comparisons between their languages and ethnographies, a method applied for the first time in the Slovenian historiography. He often emphasized that his division of history into periods would not be according to rulers or religion, but according to the nation which had lived in the territory whose history he was writing. The substance of his history is not political and religious events alone, but the ,road pursued by humanity in this small part of Europe" (Zwitter 1957: 9).

Linhart's central idea that history evolves according to laws (,order and interrelatedness govern the totality of nature") transcended the estab- 
lished view that the course of history is only a succession of accidental shifts without rhyme or reason (cf. Pogačnik, Zadravec 1973: 146). There in historical developments an order that springs not from Providence but from the natural, human and worldly laws reigns. Its causes are traceable to experience the power of life itself. History grows and dies, like a living organism. In history everything evolves according to the law of cause and effect, and in Linhart's work this principle of the Enlightenment age is made evident.

Ever since the Renaissance European historiography has looked on history in both the national perspective and the perspective of politics and religion, but it was not until Voltaire that the conception of substance in the history of civilization, and not only of political and religious history, was developed. Linhart probably found this idea in the works of Voltaire's German successors (cf. Zwitter 1957: 10-11). His historical work is actually a combination of territorial and national history, as the title of the book suggests.

Linhart's Versuch einer Geschichte..., and especially his critical and Slovenian, i.e. Slavic, conception exerted a powerful influence on later Slovenian historians and writers. His national and Slavic consciousness was best affirmed by his enthusiastic remarks that „no nation deserve as much attention of historians, philosophers and statesmen as the Slavs, the fact on which the scholarly world has already agreed”, and ,if the official science had been able to name correctly the united forces upon which the state rests after the largest homogeneous force, Austria should have been called a Slavic state, like Russia" (Zwitter 1957: 12).

Although $19^{\text {th }}$ century historical writing still suffered from uncritical regionalism and interpreted history according to provinces and periods of reign of individual rulers, Voltaire's history of civilization through Linhart's ethnographic thinking gradually stole into the „historical consciousness", finally to prevail a hundred years after Linhart's death. Without his view of Slovenian history and, more importantly, his interpretation of the central event of the Middle Ages - the conversion to Christianity, which he assessed as the subordination to German influence but at the same time stressed the higher significance of Christianity for the civilizational and cultural progress of the Slovenians - the 1836 Slovenian national epic poem, Prešeren's Krst pri Savici (Baptism at the Savica), would be inconceivable. 


\section{The Significance of Linhart's (Multilingual) Correspondence}

If Linhart's correspondence were not preserved, especially the letters to his friend Martin Kuralt with whom he had spent two years in the Stična monastery - which Linhart once described as a „bunch of clowns who seem to believe that they alone have the privilege of malice and ignorance" - we would know less about his mental profile as the Slovenian historian Ivan Prijatelj referred to it (cf. Prijatelj 1935). Linhart's letters to Kuralt, written in German and French ${ }^{6}$, represent, to say so, his poetics, his view of the world. The recurring theme of the letters are the ideas of the Enlightenment. Thus, for example, in commenting on Japelj's translation of the Bible into Slovenian he says: „As for myself, I must say that as a man I wish this translation never to be completed, although as a Carniolan and a lover of language I think differently. I don't know whether reading of the Bible can make a man happy" (Linhart 1950d: 432) ${ }^{7}$.

\section{Between the German and Slovenian, or Slovenian and German Language Respectively}

On returning from his studies in Vienna Anton Tomaž Linhart tackled the enormous task of gearing up the neglected Slovenian language for the needs of secular literature. After his German-language collection of poetry Blumen aus Krain he joined the Carniolan intellectuals who through works written not only in German sought to prove to their northern neighbours that their homeland was not as barbaric as it might seem. These same intellectuals had realized that to articulate properly one's very thoughts and feelings one must use the mother tongue. But Linhart's mother tongue was still too poor and functionally had an inadequate range of register for

6 Although this article deals primarily with Linhart's writings in the German and Slovenian language, we must not omit to mention that he also knew French and English. Almost all of his letters from the Stična monastery period were written in these two languages in order to keep their content unknown to those unauthorised.

${ }^{7}$ Boris Paternu thinks that it indicates the ,,characteristic situation when personal interest of the subject already starts to be distinguished from the interest of collective or national subject, respectively, and starts to be subordinated to it" (Paternu 1989: 738). 
a work such as Versuch einer Geschichte... In that work, as far as the language is concerned, he retained the German-cosmopolitan orientation. Just how important German was to Slovenian intellectuals even long after Linhart is evident from the fact that his Slovenian history was completely translated into Slovenian only in 1981.

\section{Literature}

Kalan F., 1979, Anton Tomaž Linhart, Ljubljana.

Kos J., 2007, Zgodnja dela Antona Tomaža Linharta, „Slavistična revija” 55, no. 3, p. $447-461$.

Linhart A.T., 1950a, Ta veseli dan ali Matiček se ženi, in: Zbrano delo I, Ta veseli dan ali Matiček se ženi, in: Zbrano delo I, ed. A. Gspan, Ljubljana, p. 35-128.

Linhart A.T., 1950b, Cvetje s Kranjskega za leto 1781, in: Zbrano delo I, ed. A. Gspan, Ljubljana, p. 185-259.

Linhart A.T., 1950c, Zbrano delo I, ed. A. Gspan, Ljubljana.

Linhart A.T., 1950d, Govor na prvi seji obnovljene ljubljanske Akademije delavnih dne 5. aprila 1781, in: Zbrano delo I, ed. A. Gspan, Ljubljana, p. 448-450.

Moravec D., 1965, Shakespeare pri Slovencih, in: Shakespeare pri Slovencih, ed. F. Koblar, Ljubljana, p. 176-315.

Paternu B., 1989, Francoska revolucija in slovenska literatura, „Sodobnost” 37, no. 8 9, p. 730-752.

Pogačnik J., Zadravec F., 1973, Zgodovina slovenskega slovstva, Ljubljana.

Poniž K.M., 2012, Nekaj ugotovitev o Linhartovi, Miss Jenny Love, „Slavistična revija” 60, no. 1, p. 1-13.

Prijatelj I., 1935, Duševni profili naših preporoditeljev, Ljubljana.

Svetina I., 2005, Imenitnik evropejski, in: Anton Tomaž Linhart, ed. I. Svetina, Ljubljana, Radovljica, p. 11-13.

Svetina I. (ed.), 2005, Anton Tomaž Linhart, Ljubljana-Radovljica.

Vidic M., 1995, Zgodovinar Anton Tomaž Linhart (1756-1795), „Radovljiški zbornik”, p. 312-321.

Zupančič M., 1972, Literarno delo mladega A.T. Linharta, Ljubljana.

Zwitter F., 1957, Anton Tomaž Linhart in njegovo zgodovinsko delo, „Naša sodobnost” V, no. 1 . 